\title{
Low-dose heparin prophylaxis against fatal pulmonary embolism*
}

\author{
SHANTI SAGAR, JULIA MASSEY, J M SANDERSON
}

British Medical fournal, 1975, 4, 257-259

\section{Summary}

A prospective randomised controlled trial in 500 patients over the age of 50 who were undergoing major surgery showed that low-dose subcutaneous heparin was an effective prophylactic measure against fatal pulmonary embolism. None of the 252 patients who received perioperative heparin cover died of fatal pulmonary embolism while eight of the 236 who did not receive heparin prophylaxis died of fatal pulmonary embolism. These results were statistically significant $(P<0.01)$.

\section{Introduction}

A preliminary perusal of the necropsy records of the North Staffordshire Hospital Centre for 1973 showed that patients over 50 years of age accounted for $97 \%$ (32 out of 33) of the deaths from pulmonary embolism (PE) after surgery. We designed a prospective, randomised, controlled, and multiunit trial of patients over 50 years old to determine whether perioperative low-dose heparin (as used by Kakkar et $a l^{1}$ ) would be effective prophylaxis against postoperative fatal PE. Five-hundred patients were studied during the period April 1973 to March 1974 , and a preliminary report was published in $1974 .{ }^{2}$ We now present the final results of this one-year study.

\section{Patients and methods}

The trial included patients under the care of two thoracic surgeons, one urological surgeon, and five general surgeons in two hospitals. The trial was co-ordinated by one of us (SS) with the help of nursing and surgical colleagues. The hospital medical ethics committee approved the trial and the informed consent of each patient was obtained. There was no other change in the management of the patients, and the surgeons were at liberty to stop the injections of heparin at any stage during the trial.

Five-hundred patients due for elective major surgery participated in this trial (patients undergoing endoscopy and minor surgery were

*Based on a paper delivered at a meeting of the Surgical Research Society of Great Britain and Ireland held in London on 4 January 1975.

North Staffordshire Hospital Centre, Stoke-on-Trent, Staffordshire SHANTI SAGAR, FRCS, surgical registrar (present address: Department of Surgery, King's College Hospital Medical School, London SE5)

JULIA MASSEY, BSC, systems analyst

J M SANDERSON, FRCS, consultant thoracic surgeon excluded because the criterion for major surgery was an operating and anaesthetic time longer than one hour). Cambridge tables were used to allocate patients at random to a heparin prophylaxis group or a control group. Several consecutive patients underwent detailed blood coagulation studies (thrombin clotting time, activated partial thromboplastin time, thromboelastograms) and the results are reported elsewhere. ${ }^{3}$

Haemoglobin changes (before and one week after operation) were recorded in 347 consecutive patients for comparison. Blood loss was compared in thoracic patients and, when possible, in patients undergoing general and urological surgery. The transfusion requirements of 466 patients were analysed.

Patients in the heparin group received 5000 IU heparin sodium subcutaneously two hours before operation and every 12 hours for five days. The nurses were asked to maintain a separate chart designed to indicate that the patient had in fact received heparin in this regimen.

A necropsy was requested for all patients who died during this trial. The necropsies were performed by independent consultant pathologists who were not informed of the patient's allocation. They were asked to state the primary cause of death and the presence or absence of pulmonary emboli. If pulmonary emboli were present they were also asked to state whether these were major or minor and fatal or contributory.

The data were analysed by the statistician (JM) using the $\chi^{2}$ test (with Yates's correction) in frequencies and Student's $t$ test on measureable quantities-for example, length of stay, blood loss, etc.

\section{Results}

Of the 500 patients studied during 12 months 264 were allocated to the heparin group and 236 to the control group (table I). Twelve patients did not receive the full prescribed course of heparin but were not totally excluded from statistical analysis. Four patients were withdrawn because of suspicion of increased postoperative bleeding and another eight were withdrawn because they were allocated to the heparin group but did not receive any heparin (three by surgeon's choice and five by mistake). The types of surgery performed are shown in table II.

TABLE II-Operative procedures in 264 patients treated with heparin and 236 controls

\begin{tabular}{|c|c|c|c|c|c|c|}
\hline & & $\begin{array}{c}\text { Heparin } \\
\text { group }\end{array}$ & $\begin{array}{l}\text { Control } \\
\text { group }\end{array}$ & & $\begin{array}{c}\text { Heparin } \\
\text { group }\end{array}$ & $\begin{array}{l}\text { Control } \\
\text { group }\end{array}$ \\
\hline $\begin{array}{l}\text { Thoracic } \quad . . \\
\text { Gastric } \\
\text { Biliary } \\
\text { Intestinal } \\
\text { Laparotomy } \\
\text { (without other } \\
\text { procedures) }\end{array}$ & $\begin{array}{l}\because \\
\because \\
\cdots \\
\therefore\end{array}$ & $\begin{array}{l}42 \\
46 \\
40 \\
36 \\
\\
\\
14\end{array}$ & $\begin{array}{l}48 \\
38 \\
37 \\
34 \\
\\
\\
6\end{array}$ & $\begin{array}{l}\text { Laparotomy } \\
\quad \text { (with palliation) } \\
\text { Urological ... } \\
\text { Prostatectomy... } \\
\text { Hiatus hernia .. } \\
\text { Miscellaneous.. }\end{array}$ & $\begin{array}{l}23 \\
16 \\
21 \\
11 \\
15\end{array}$ & $\begin{array}{l}18 \\
10 \\
16 \\
12 \\
17\end{array}$ \\
\hline
\end{tabular}

Mortality-Necropsies were carried out on 60 of the 66 patients who died. Each of the six patients on whom a necropsy was not performed had terminal carcinomatosis (four in the control group and

TABLE I-Characteristics of patients admitted to trial. Results are means $\pm S E$ of mean

\begin{tabular}{|c|c|c|c|c|c|c|c|c|c|}
\hline & \multirow{2}{*}{$\begin{array}{c}\text { No of } \\
\text { patients }\end{array}$} & \multirow{2}{*}{ Men } & \multirow{2}{*}{ Women } & \multirow{2}{*}{$\underset{\text { (years) }}{\text { Age }}$} & \multirow{2}{*}{$\begin{array}{l}\text { Preoperative stay in } \\
\text { hospital } \\
\text { (d) }\end{array}$} & \multicolumn{4}{|c|}{$\begin{array}{l}\text { Length of operation } \\
(\mathrm{h})\end{array}$} \\
\hline & & & & & & $1 \mathrm{hr}$ & $1-2$ & $2-3$ & $>3$ \\
\hline $\begin{array}{l}\text { Heparin group: } \\
\text { Actually heparinised } \\
\text { Discontinued } \\
\text { Control group }\end{array}$ & $\begin{array}{r}252 \\
12 \\
236\end{array}$ & $\begin{array}{r}155 \\
4 \\
134\end{array}$ & $\begin{array}{r}97 \\
8 \\
102\end{array}$ & $\begin{array}{l}63.4 \pm 0.6 \\
66.0 \pm 2.9 \\
62.2 \pm 0.5\end{array}$ & $\begin{array}{l}4.6 \pm 0.3 \\
5.0 \pm 1.2 \\
4.9 \pm 0.3\end{array}$ & $\begin{array}{r}102 \\
6 \\
88\end{array}$ & $\begin{array}{r}119 \\
4 \\
115\end{array}$ & $\begin{array}{r}31 \\
1 \\
22\end{array}$ & $\begin{array}{l}12 \\
1 \\
11\end{array}$ \\
\hline
\end{tabular}


two in the heparin group). Eight patients in the control group died of fatal PE (table III) in contrast to none in the heparin group (table IV; $P<0.01$ ). There was no statistically significant difference between the two groups in the number of deaths in which PE was contributory. Three of the 12 patients who did not receive the full prescribed course of heparin died. Minor incidental PE was found in one of them at necropsy. He was included in the heparin group for the analysis of results.

Blood loss-An obvious possible side effect of heparin is the increased risk of bleeding. To assess this we decided to compare the fall in haemoglobin values and the numbers of patients who required blood transfusions, as well as the actual quantities of blood given in each group. The fall in haemoglobin values in the 347 patients studied did not show any difference between the two groups. Altogether 114 patients in the heparin group and 122 in the control group received perioperative transfusion (table $\mathrm{V}$ ). The mean quantity of blood transfused was 2.3 units in the heparin group and 2.7 in the control group.

The surgeons and registrars of all the units were asked to fill in a questionnaire on this trial and none of them expressed any clinical impression of increased operative or postoperative bleeding. Five patients developed minor haematomas at the site of injection.

TABLE III-Operative procedures and diagnoses in eight control patients dying from pulmonary embolism and comparison with similar cases

\begin{tabular}{|c|c|c|c|c|c|}
\hline \multirow[b]{2}{*}{ Operation } & \multirow[b]{2}{*}{ Diagnosis } & \multirow{2}{*}{$\begin{array}{l}\text { Age } \\
\text { and } \\
\text { Sex }\end{array}$} & \multirow{2}{*}{\begin{tabular}{|} 
Day of \\
death \\
after \\
operation
\end{tabular}} & \multicolumn{2}{|c|}{$\begin{array}{l}\text { No of similar } \\
\text { cases }\end{array}$} \\
\hline & & & & $\begin{array}{l}\text { Control } \\
\text { group } \\
(\mathbf{n}=80)\end{array}$ & $\begin{array}{l}\text { Heparin } \\
\text { group } \\
(\mathrm{n}=85)\end{array}$ \\
\hline $\begin{array}{l}\mathrm{L} \text { and } \mathrm{P} \text { surgery } \\
\mathrm{L} \text { and } \mathrm{P} \text { surgery } \\
\text { Hemicolectomy } \\
\text { Anteroposteroir }\end{array}$ & $\begin{array}{l}\text { Carcinoma colon } \\
\text { Carcinoma stomach } \\
\text { Carcinoma caecum }\end{array}$ & $\begin{array}{ll}60 \mathrm{~F} \\
73 \mathrm{~F} \\
77 \mathrm{M}\end{array}$ & $\begin{array}{l}3 \\
6 \\
9\end{array}$ & $\begin{array}{l}9 \\
8 \\
4\end{array}$ & $\begin{array}{l}9 \\
7 \\
7\end{array}$ \\
\hline $\begin{array}{l}\text { resection of rectum } \\
\text { Pnuemonectomy } \\
\text { Prostatectomy } \\
\text { Lobectomy } \\
\text { Vagotomy and }\end{array}$ & $\begin{array}{l}\text { Carcinoma rectum } \\
\text { Carcinoma bronchus } \\
\text { Adenoma of prostate } \\
\text { Lung cyst } \\
\text { Chronic duodenal }\end{array}$ & $\begin{array}{ll}63 & M \\
64 & F \\
65 & M \\
58 & M\end{array}$ & $\begin{array}{r}6 \\
4 \\
10 \\
10\end{array}$ & $\begin{array}{r}8 \\
7 \\
15 \\
3\end{array}$ & $\begin{array}{r}11 \\
9 \\
19 \\
5\end{array}$ \\
\hline pyloroplasty & ulcer & $67 \mathrm{~F}$ & 36 & 24 & 20 \\
\hline
\end{tabular}

$\mathrm{L}$ and $\mathrm{P}$ surgery $=$ Laparotomy and palliative surgery.

TABLE IV-Mortality in both groups

\begin{tabular}{l|c|c|c}
\hline Deaths: & From all causes & Due to PE & $\begin{array}{c}\text { In which PE } \\
\text { was contributory }\end{array}$ \\
\hline $\begin{array}{l}\text { Control group } \\
\text { Heparin group }\end{array}$ & 38 & 8 & 4 \\
\hline
\end{tabular}

\section{Discussion}

The characteristics of the patients, their lesions and operations, and the deaths other than those due to PE were sufficiently similar in the two groups to confirm that the sampling was effectively random (see tables I, II, and IV).

The overall mortality was high. This could have been due to several reasons: age of patients (mean age $>60$ years), severity of surgery ( 304 patients had surgery lasting $>1$ hour), and the presence of malignant disease (present in 234 patients; table VI). The incidence of fatal PE $(3.4 \%)$ was higher than in most reported
TABLE VI-Deaths in both groups according to original disease

\begin{tabular}{l|l|c|c|c}
\hline \multirow{2}{*}{ Disease } & \multicolumn{2}{|c|}{ Heparin group } & \multicolumn{2}{c}{ Control group } \\
\cline { 2 - 5 } & No & No of deaths & No & No of deaths \\
\hline Benign & 136 & 6 & 130 & 11 \\
Malignant & 128 & 22 & 106 & 27 \\
\hline
\end{tabular}

series, but this could also be explained by the fact that this was a high-risk group.

Eight of the controls and none of the heparin-treated patients died primarily because of PE, and the difference between the groups was significant at the $1 \%$ level $\left(P<0.01\right.$ for $\chi^{2}$ with Yates's correction). One of the deaths in the heparin group, however, was reported by the pathologist as contributed to by pulmonary embolus, but may perhaps have been considered by a clinician as primarily due to PE. If this were so-that is, there were eight deaths in the control group and one in the heparin group-the results would still be significant but only at the $5 \%$ level. This case is described below because its classification is difficult in our context.

Case report-This patient was a man of 66 who had a carcinoma of the lower end of the oesophagus with local nodal and numerous liver metastases. He had a history of dysphagia and two weeks' dyspnoea with no significant changes seen on a radiograph of lung fields. He was treated by insertion of a MousseauBarbin tube through the growth for palliation and was well for three days. On the fourth day he developed cough and bloodstained sputum, and the right leg was swollen. Warfarin was started. $\mathrm{He}$ remained short of breath, deteriorated, and died on the 10th day after operation. Necropsy showed extensive, adherent, and organised emboli in the left main and peripheral pulmonary arteries. In the left lower lobe was a haemorrhagic infarct. The rest of the lung parenchyma showed pulmonary oedema. There was evidence of pulmonary hypertension with right ventricular hypertrophy and a pale, soft, left ventricle with minimal atheroma of coronary arteries. No thrombi were found in the leg veins examined. There was a transverse ulcer of the oesophagus above the upper lip of the Mousseau-Barbin tube and the adjacent mediastinum were filled by altered blood.

According to our criteria the pathologist supplied the answer - that is, pulmonary embolus was a contributory cause. It is clinically likely that embolism occurred two weeks before operation and contributed to his death.

Other authors have reported results showing that postoperative deep venous thrombosis can be reduced using dextran, ${ }^{5}$ calf compression, ${ }^{6}$ or calf stimulation. ${ }^{7}$ It is likely but unproved statistically that these measures also reduce the incidence of fatal PE. Each has its limitations and hazards: dextran may cause haemodilution and may precipitate congestive cardiac failure, and calf compression and stimulation may not be readily practicable for all patients in a busy surgical ward. Heparin is cheap and the regimen can be readily fitted into the ward routine.

The "theoretical" danger of increased bleeding due to heparin was not apparent in this study. The selection of high-risk patients for this course of management covers most of the patients at risk from postoperative $\mathrm{PE}$ and therefore decreases the load on the already strained nursing staff.

If death due to PE could be prevented a significant cause of

TABLE V-Postoperative effects. Results are means $\pm S E$ of mean

\begin{tabular}{|c|c|c|c|c|c|c|}
\hline & \multirow{2}{*}{$\begin{array}{l}\text { Postoperative } \\
\text { stay in hospital } \\
\text { (days) }\end{array}$} & \multicolumn{4}{|c|}{ - Blood transfusion } & \multirow{2}{*}{$\begin{array}{l}\text { Decrease in } \\
\text { haemoglobin from } \\
\text { before to after } \\
\text { operation } \\
(\mathrm{g} / \mathrm{dl})\end{array}$} \\
\hline & & $\begin{array}{l}\text { Total No of } \\
\text { patients } \\
\text { recorded }\end{array}$ & $\begin{array}{l}\text { No with } \\
\text { no transfusion }\end{array}$ & $\begin{array}{l}\text { Units transfused } \\
\text { in all patients } \\
\text { recorded }\end{array}$ & $\begin{array}{c}\text { Units of those } \\
\text { receiving } \\
\text { transfusion }\end{array}$ & \\
\hline Actually heparinised $(n=252)$ & $11.6 \pm 0.5$ & 238 & 124 & $1 \cdot 1 \pm 0 \cdot 1$ & $2 \cdot 3 \pm 0 \cdot 1$ & $\begin{array}{l}0.9 \pm 0 \cdot 1 \\
(\mathrm{n}=179)\end{array}$ \\
\hline Control group $(n=236)$ & $11.9 \pm 0.5$ & 228 & 106 & $1 \cdot 4 \pm 0 \cdot 1$ & $2 \cdot 7 \pm 0 \cdot 1$ & $\begin{array}{l}0.9 \pm 0.1 \\
(\mathrm{n}=168)\end{array}$ \\
\hline
\end{tabular}


mortality would be eliminated from major surgery. Our multiunit study of patients with a high risk of fatal PE undergoing various major surgical procedures showed that heparin significantly reduced the incidence of fatal postoperative PE.

We thank Mr J M Buchanan, Mr V V Kakkar, and Mr A F Higgins for their help in the preparation of this article; Dr M M Koshi for his help in the project; Messrs P M Higgins, W Sewell, L J Lawson, J G Gray, and E G Brewin, who allowed patients under their care to be included in this trial; the consultant pathologists for their necropsy reports; Dr F Hails, coroner, Stoke-on-Trent, for his co-operation; Mrs S Docksey for her painstaking secretarial work; and, finally, but not least, the nursing staff and junior colleagues for their help.
Requests for reprints should be addressed to Mr S Sagar, Department of Surgery, King's College Hospital Medical School, London SE5 8RX.

\section{References}

1 Kakkar, V V, et al, Lancet, 1972, 2, 101

2 Sagar, S, British Medical fournal, 1974, 1, 153.

3 Sagar, S, fournal of the Royal College of Surgeons of Edinburgh, in press.

${ }^{4}$ Kakkar, V V, et al, Lancet, 1971, 2, 669.

5 Bonnar, J, and Walsh, J, Lancet, 1972, 1, 614.

6 Sabri, S, Roberts, V C, and Cotton, L T, British Medical fournal, 1971, $3,82$.

${ }^{7}$ Browse, N L, and Negus, D, British Medical fournal, 1970, 3, 615.

\title{
Comparison of fibreoptic endoscopy in acute upper gastrointestinal haemorrhage in Africans and Europeans
}

\author{
A C B WICKS, G E THOMAS, D J CLAIN
}

British Medical fournal, 1975, 4, 259-260

rhage. One African and nine Europeans had previously been operated on for peptic ulceration. The African patients were seen at Harari Hospital, which is the major referral centre for a population of 2000000 and the general hospital for the Greater Salisbury area. The European patients were referred to one of us (DJC) in a private consulting practice. Classified according to six social grades, ${ }^{2} 4 \%$ of Africans and $32 \%$ of Europeans were in classes 1 and 2 (professional and skilled), and $36 \%$ of Africans and $1.5 \%$ of Europeans were in classes 5 and 6 (unskilled and labourers). Within the gradings there was a large pay differential between the races. The lower social grades of Africans consumed significantly more maize meal and less spirits, meat, eggs, potatoes, fish, and jam than the Europeans.

Patients received diazepam $(5-20 \mathrm{mg})$ by intravenous injection after a detailed explanation of the nature of the procedure. Hyoscine butylbromide (20-40 mg) was often used to reduce peristalsis. An Olympus GIF-D end-viewing panendoscope or an Olympus JFB2 side-viewing duodenoscope, or both, were used. The endoscope was passed with the patient in the left lateral position. to herbal medicines, were more common in the Africans but the difference was not significant. The study was not designed to determine reduced mortality since the introduction of endoscopy, but management, especially in the Africans, was aided by early recognition of haemorrhage from oesophageal varices and acute gastric erosions.

\section{Introduction}

Flexible fibreoptic instruments have revolutionised the early diagnosis of gastrointestinal haemorrhage and have led to a reassessment of the incidence of underlying lesions. ${ }^{1}$ We used panendoscopy to compare the causes of gastrointestinal bleeding in two racial groups of widely different socioeconomic status and dietary habit. We describe below our experience in African and European patients.

\section{Patients and methods}

From June 1972 to July 1974222 patients (138 Africans and 84 Europeans) underwent endoscopy for upper gastrointestinal haemor-

\footnotetext{
Department of Medicine, University of Rhodesia, Salisbury, Rhodesia

A C B WICKS, MD, MRCP, senior lecturer

G E THOMAS, MRCP, lecturer

D J CLAIN, MD, MRCP, consultant physician
}

\section{Results}

The mean age of the Africans was lower (38 years, range 12-76 years) than that of the Europeans (51 years, range 19-82 years), and the male: female ratio was about $3: 1$ in both races. These patients constituted $37 \%$ of the Africans and $26 \%$ of the Europeans referred for upper gastrointestinal endoscopy during the two-year period. Altogether $110(80 \%)$ of the Africans and $(79 \%) 66$ of the Europeans presented with both haematemesis and melaena; the remainder had melaena alone. Forty-one (30\%) of the Africans and $26(31 \%)$ of the Europeans underwent endoscopy within two days of bleeding, $112(81 \%)$ and $64(76 \%)$ within seven days, and $26(19 \%)$ and $20(24 \%)$ after seven days.

Table I shows the results in both groups. There were no complications. A bleeding source was not found in 18 Africans and 12 Europeans. One African was found to have colonic bleeding at surgery, and in a second necropsy showed no cause of bleeding. The endoscope failed to enter the duodenum in three Africans, who were subsequently operated on for duodenal ulcer. Nearly half the examinations with negative findings in the Africans occurred seven to 14 days after haemorrhage. Seven of the 12 Europeans with negative findings underwent endoscopy more than a week after bleeding, and eight had presented with melaena alone. One had a gastric and another a duodenal ulcer at operation.

The percentage of positive diagnoses was similar for the Africans and Europeans. Duodenal ulcers were the commonest cause of bleeding in both groups, followed by gastric ulcers, which were present in $17 \cdot 3 \%$ of the Africans and $20.2 \%$ of the Europeans. Of the 36 African and 22 European patients with duodenal ulcers only four and 